\title{
Morpho-Structural Mapping Constraints from Geophysical and Test Pit Investigations: Case Study of the Bomkoul Locality in Douala Sedimentary Basin, Cameroon, Central Africa
}

\author{
Michel Bertrand Mbog ${ }^{*}$, Jean Victor Kenfack1, Gilbert François Ngon Ngon², \\ Bernard Tassongwa ${ }^{1}$, Elie Constant Bayiga ${ }^{2}$, Jacques Etame ${ }^{2}$ \\ ${ }^{1}$ Department of Earth Science, Faculty of Science, University of Dschang, Dschang, Cameroon \\ ${ }^{2}$ Department of Earth Science, Faculty of Science, University of Douala, Douala, Cameroon \\ Email: *michelbertrandmbog@yahoo.fr
}

How to cite this paper: Mbog, M. B., Kenfack, J. V., Ngon, G. F. N., Tassongwa, B., Bayiga, E. C., \& Etame, J. (2019). Morpho-Structural Mapping Constraints from Geophysical and Test Pit Investigations: Case Study of the Bomkoul Locality in Douala Sedimentary Basin, Cameroon, Central Africa. Journal of Geoscience and Environment Protection, 7, 136-153. https://doi.org/10.4236/gep.2019.710011

Received: August 2, 2019

Accepted: October 28, 2019

Published: October 31, 2019

Copyright $\odot 2019$ by author(s) and Scientific Research Publishing Inc. This work is licensed under the Creative Commons Attribution International License (CC BY 4.0).

http://creativecommons.org/licenses/by/4.0/

\begin{abstract}
A survey using the electrical resistivity and test pit methods is carried out in the Douala sub-basin in order to investigate the sub-surface layering and evaluate the thickness of each layer through the variation of the resistivity with the depth. Applying the Schumberger array, a total of 48 vertical electrical sounding is conducted along 8 profiles directed W-E and using traditional method, 25 test pits with depth between 15 and 19 meters are done. Qualitative interpretation is carried out through the resistivity and test pit maps. The test pit maps reveal the presence of the following layers: The first layer of thickness varies from 0.2 to $2.0 \mathrm{~m}$ (average of $1.9 \mathrm{~m}$ ). The thickness of the second layer varies between 0.2 and $4.0 \mathrm{~m}$ with an average of $2.8 \mathrm{~m}$. The thickness of the third layer is between 2.0 and $4.0 \mathrm{~m}$ with an average of $3.8 \mathrm{~m}$. That of the fourth and fifth layers ranges respectively between 4.0 and $6.0 \mathrm{~m}$ (average of $5.4 \mathrm{~m}$ ) and between 2.0 and $6.0 \mathrm{~m}$ with an average of $4.4 \mathrm{~m}$. Isoresistivities maps from resistivities computed for different $A B / 2$ values (1.5; 4.4; $13.5 ; 19 ; 27.5 ; 58 \mathrm{~m})$ are generally characterized by the apparent resistivities which define many domains in function of the $A B / 2$ values. The superficial layer is characterized by electric resistivity values ranging from 720 to 2073 $\Omega \mathrm{m}$ for $A B / 2=1.5 \mathrm{~m}$ and probably represents pedologic materials. For other values of $A B / 2$, resistivity varies from 253 to $32,381 \Omega \mathrm{m}(A B / 2=4.4 \mathrm{~m}), 0.1$ to $1838(A B / 2=13.2 \mathrm{~m})$ with an average of $341 \Omega \mathrm{m}, 0.3$ to $1608 \Omega \mathrm{m}(A B / 2=$ $19 \mathrm{~m})$ with an average of $279 \Omega \mathrm{m}, 6.4$ to $1427 \Omega \mathrm{m}(A B / 2=27.5 \mathrm{~m})$ with an average $291 \Omega \mathrm{m}$, and 19.7 to $3555 \Omega \mathrm{m}(A B / 2=58 \mathrm{~m})$ with an average of 850 $\Omega \mathrm{m}$. These different values of resistivity represent the sedimentary materials.
\end{abstract}




\section{Keywords}

Douala Sub-Basin, Isoresistivity Map, Test Pit, Sedimentary Materials, Thickness

\section{Introduction}

The development of a country or even a region depends among other on the wealth of the subsoil. The superficial layer of soil being this interesting part of agriculture, the anchoring of the foundations of engineering structures, the search for certain natural resources, etc. sedimentary basins generally have a more or less complex structure and are sometimes interesting areas for the exploration of deposits. In the Douala sub-basin (south Cameroon, central Africa), several stratigraphic studies, such as Von Koenen (1896), Solger (1904), Riedel (1932), Dartevelle and Brebion (1956), Dartevelle et al. (1957), Reyre (1966), Dumort (1968), Njike Ngaha (1984), Regnoult (1986), Brownfield and Charpentier (2006), showed clay deposits in various formation, the main being the formations of Mundeck, Logbadjeck, Logbaba, N'kapa, Matanda, Souellaba and Wouri. However, the Miocene Matanda formation (Dumort, 1968; Njike Ngaha, 1984 ) is one of the most interesting because of its stratigraphic position (it outcrops and is the least eroded, with a high potential for clays) and its geographical location (in and economic city with the advantage of considering and establishment in industries). In the Bomkoul area, Njopwouo and Wandji (1985) and Njopwouo and Kong (1986) used to show the kaolinitic nature of two identified raw clayey materials (gray and spotted clays) by chemical and mineralogical analysis. Elimbi \& Njopwouo (2002) have also shown that these raw clays materials have a good characteristic for ceramics. Njopwouo (1984) studied the use of these clays materials in the polymerization of styrene and in the reinforcement of natural rubber. The preliminary work done by Mbog (2010) and Maliengoue (2010) describe the clay of materials of the Bomkoul area. In addition, the works of Ngon Ngon et al. (2012) have shown that these clays can be used in the manufacture of bricks, stoneware, and tiles, with the exception of pyrite rich clays. Ngon Ngon et al. (2012) reveal three facies: gray, dark gray and variegated. The studies conducted by Mbog (2016) focused exclusively on the differentiation of soil clay from the alteration of sedimentary materials, sedimentary clays which are deposits of fine sediments. However, despite these works, many shadows remain and require in-depth studies to better understand the mapping of the local and regional structures of this locality. In addition, the drillings and pits made so far have not completely crossed the different types of materials (sand, clay and sand stone) to ease the differentiation in depth their limits and geometry of deposit.

\section{Geological Setting}

The study area is located in Douala sub-basin which forms the northern part of 
the Cameroon Douala/Kribi-Campo Basin. The Douala sub-basin is located in the gulf of guinea between the Cameroun Volcanic Line in the north and the Kribi-Campo sub basin in the south. It is characterized by low surface of erosion ( $<200 \mathrm{~m}$ of altitude) which corresponds to interfluves with convex and convexo-concave hillsides joined to narrow and either more or less deep valleys. The lithostratigraphy of Douala sub-basin is made of seven major Formations related to its geodynamic and sedimentary evolution (Nguene et al., 1992; Regnoult, 1986; SNH/UD, 2005). 1) The syn-rift period represented by the Mundeck Formation (Aptian Cenomanian) is discordant onto the Precambrian basement and consists of continental and fluvio-deltaic deposits, i.e. clays, coarse-grained sandstones, conglomerates. The post rift sequence includes; 2) The Logbadjeck Formation (Cenomanian-Campanian), discordant onto the Mundeck Formation and composed of microconglomarates, sand, sandstone, limestone, and clays; 3) The Logbaba Formation (Maastrichtian), maintly composed of sandstone, sand and fossiliferous clays; 4) The N'kapa Formation (Paleocene Eocene), rich in marl and clay with lenses of sand and fine to coarse-grained sandstone; 5) The Souellaba Formation (Oligocene) lying unconformably on N'kapa deposits and characterized by marl deposits with some interstratified lenses and sand channels; 6) The Matanda Formation (Miocene), dominated by deltaic facies interstratified with volcano-clasties layers; and 7) The Wouri Formation (Plio-Pleistocene) which consists of gravelly and sandy deposits with a clayey or kaolinic matrix.

The Bomkoul area is located to the north-east of Douala region between latitudes 48,050 to $48,060 \mathrm{~N}$ and longitudes 98,470 to $98,490 \mathrm{E}$ in Douala sub-basin, within a humid equatorial climate. The geomorphology of the study area is a coastal plain with low altitudes $(14-120 \mathrm{~m})$. This area shows hills with flat and sharp summits ant is deeply incised by $\mathrm{V}$ and $\mathrm{U}$ shape valleys. According to the geological map of SNH/UD (2005) report, the relative age of the deposit of Bomkoul area is Upper Tertiary Miocene-Pliocene corresponding to the Matanda-Wouri-Formation (Figure 1).

\section{Data and Method}

In order to evaluate the geoelectrical resistivity map of the area, resistivity data was collected using an ABEM 1000 Terrameter following the step of $1 \mathrm{~km}$. Fourty eight Vertical Electrical Sounding (VES) numbered S1... S48 and twenty four pits were done (Figure 2). The pits were done following morpho-sequential method. Each value of apparent resistivity was obtained by Schlumberger method and the resistivity maps deduce. The altitudes around VES stations range from 20 to $60 \mathrm{~m}$ with the average of $35 \mathrm{~m}$.

Electrical resistivity $(\rho)$ is an intrinsic property of all earth materials. Resistivity is the reciprocal electrical current. In most porous rock systems, ionic conduction by interstitial fluids and surface conduction at the interface between solid rock matrices and electrolytic solution are responsible for a major part of the electric current flowing through a formation (Keleko et al., 2013). Electrical 


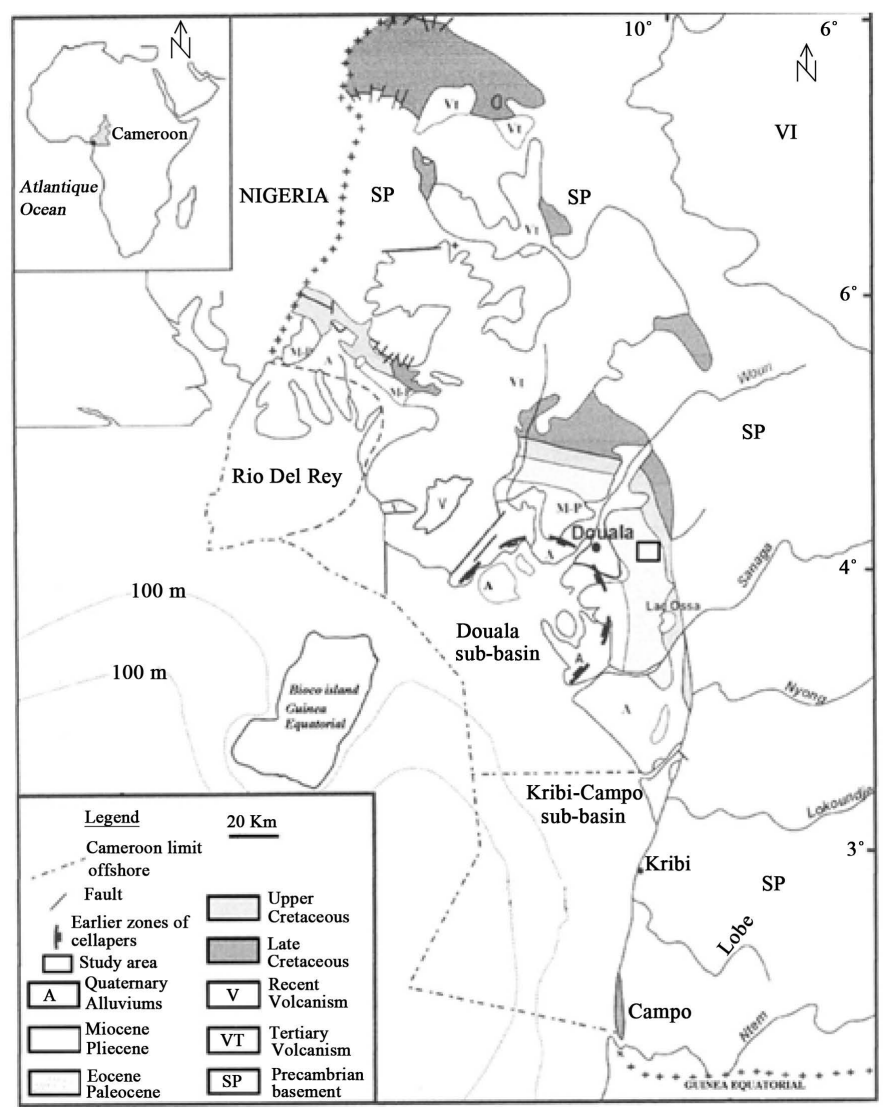

Figure 1. Geological map of Douala sub-basin (SNH/UD, 2005).

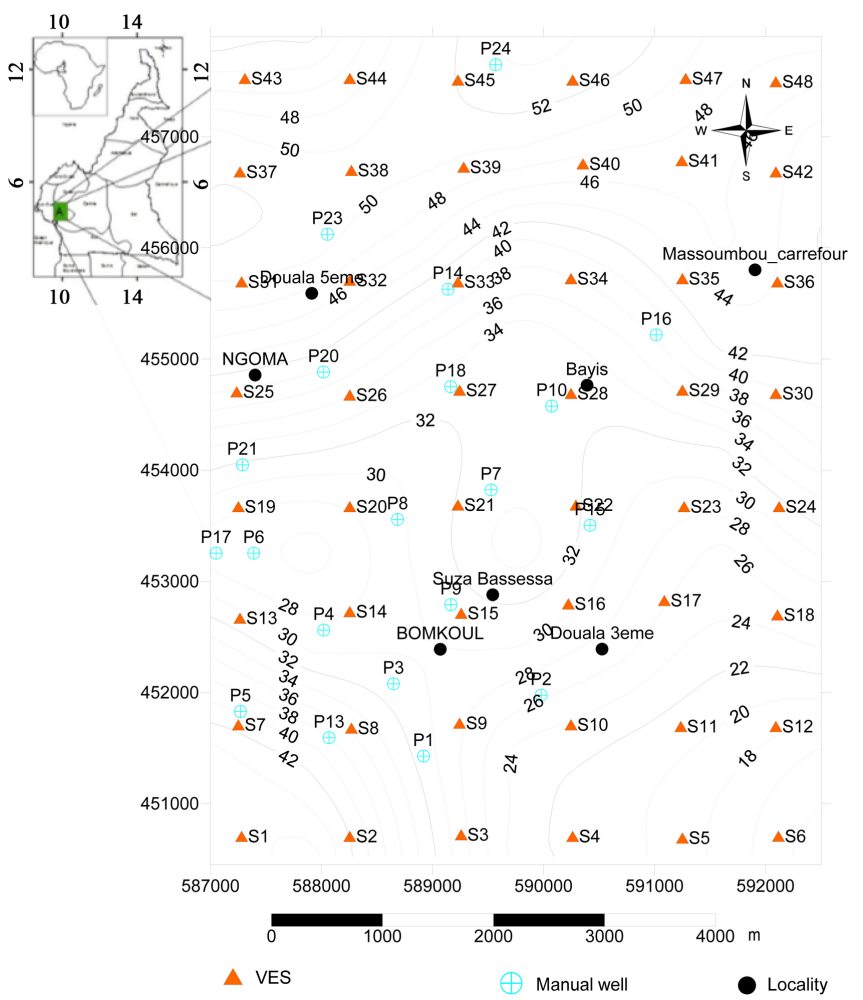

Figure 2. Repartition of test pits and vertical electrical sounding maps. 
resistivity techniques measure earth resistivity by passing and electrical current into the ground and measuring the resulting potentials created in the earth.

This method involves the supply of direct current into the grown through a pair of current electrodes and the measurement of the resulting potential through another pair of electrodes called potential electrodes. Since the current is known and the potential can be measured, an apparent resistivity can by calculated using Equation (1)

$$
\rho_{a}=\frac{\pi \Delta V}{I}\left[\frac{\left(\frac{A B}{2}\right)^{2}-\left(\frac{M N}{2}\right)^{2}}{M N}\right]
$$

$A B$ : current electrode spacing in meter, $\triangle V$ : potential differences in volts, $M N$ : potential electrode spacing in meter, $I$ : electric current in amperes, $\pi=22 / 7, \rho_{a}$ : apparent resistivity.

For Schlumberger soundings, the apparent resistivity values $\rho_{a}$ were plotted against half current electrode spacing $(A B / 2)$ on a log-log graph and a smooth curve was drawn for each of the soundings. Then, the sounding curve was interpreted to determine the true resistivities and thicknesses of the sub surface layer. The resistivity of the subsurface material observed is a function of the magnitude of the current, the recorded potential difference and the geometry of the electrode array used. The depth of penetration is proportional to the Schlumberger array which uses closely spaced potential electrodes and widely spaced current electrodes. Generally, the depth of infiltration is small in this method and only shallow subsurface layers have been surveyed (Danielsen et al., 2007).

A total number of 48 Vertical Sounding (VES) with a step of $1 \mathrm{~km}$ were conducted along 8 geometric profiles. The soundings are arranged along profiles ranging approximately East-West. The Schlumberger electrode configuration having a maximum current electrode spread of $166 \mathrm{~m}$ was used. The current electrode spacin begins with a distance equal to $3 \mathrm{~m}$ and extends up to $166 \mathrm{~m}$.

The results of the interpretation are represented in the form of the resistivity values that can be used for preparing the isoapparent electric resistivity map which reflect both lateral and vertical variations in resistivity. The surveys were carried out in dry weather facilitating implementation. The investigation area is very accessible in some places and the device could extend to over $240 \mathrm{~m}$ at the surface. Theoretical investigation depth is given by Barker's formula (Banton \& Bangoy, 1997) as Depth $=0.19 \times \mathrm{L}$ where $\mathrm{L}=A B$ for each measuring point.

The field results of the study are presented in qualitative interpretations of resistivity maps and quantitative interpretation of test pits. In the qualitative interpretations, the shape of the field curve is observed to get an idea qualitatively about the number of layers. The results involved isoapparent electrical resistivity maps and help to study the variation of the resistivity in the precise depth. This isoapparent resistivity maps reflect the lateral variation of apparent resistivity over a horizontal plane at a certain depth. In other words, theses maps indicate 
distribution of apparent resistivity in the area against distance of current electrodes. The maximum depth penetration of the $A M N B$ method is $1 / 3$ to $1 / 4$ of the maximum distance of current electrodes (Frohlich et al., 1996). In the quantitative interpretation of test pits, layer thickness is obtained and helps to evaluate the real thickness of subsurface layer and better understand the variation of resistivity with the depth. Since current is conducted electrolytically by the groundwater (in the saturated layers) and surfacely by effective surface of minerals (in the dry layers) (Zohdy et al., 1974), the low values of apparent resistivity are attributed to the presence of saturated layer and the high values in other areas to the presence of unconsolidated and dry layer.

\section{Results}

\subsection{Isoapparent Electric Resistivity Maps}

In the case study, isoapparent electric resistivity maps were constructed at $A B=$ 3, 8.8, 26.4, 55 and $116 \mathrm{~m}$. The choice of $A B$ values depends on the variability of resistivity values observed on maps. These maps reflect the lateral variations of the electric resistivity at depths of $0.75-1,2.20-2.93,6.6-8.8,13.75-18.33$ and 29 - $38.67 \mathrm{~m}$, respectively.

\section{- Isoapparent electric resistivity map for $A B=3 \mathrm{~m}$}

Isoapparent resistivity map for $A B=3 \mathrm{~m}$ reflects the lateral variation over a horizontal plane at a depth of about $0.75-1.00 \mathrm{~m}$. The resistivity varies enough increasing up to $2100 \Omega \mathrm{m}$ at some point and decreasing up to $700 \Omega \mathrm{m}$ at other points (Figure 3(a)). This may imply the heterogenous nature of the formations. It showed the apparent resistivity values around stations S1, S2, S4, S5, S6, S7, S10, S11, S13, S18, S20, S23, S27, S29, S34, S40, S44, S45 and S48 lower than others between $700-1200 \Omega \mathrm{m}$. These zones of lower apparent resistivity could represent the favorable zones for agriculture in the dry season.

\section{- Isoapparent electric resistivity map for $A B=8.8 \mathrm{~m}$}

Figure $3(\mathrm{~b})$ reflects the lateral variation over a horizontal plane at a depth of about $2.20-2.93 \mathrm{~m}$.

Resistivities values are almost constant around $2000 \Omega \mathrm{m}$ in the entire area except the area around station $S 9$ where it increases up to $36,000 \Omega \mathrm{m}$ indicating the intrusive formation.

\section{- Isoapparent electric resistivity map for $A B=26.4 \mathrm{~m}$}

Figure $3(c)$ represents the lateral variation over a horizontal plane at a depth of about $6.60-8.80 \mathrm{~m}$.

It shows a relatively constant resistivity $(0-700 \Omega \mathrm{m})$ but for some points there is a rise in resistivity. Exception is that of stations S1, S2 and S48 where the values of resistivities vary between $700-2300 \Omega \mathrm{m}$. Low resistivity indicates the presence of aquifer in the area.

\section{- Isoapparent electric resistivity map for $A B=38 \mathrm{~m}$}

Figure $3(\mathrm{~d})$ represents the lateral variation over a horizontal plane at a depth of about $9.5-12.67 \mathrm{~m}$. 


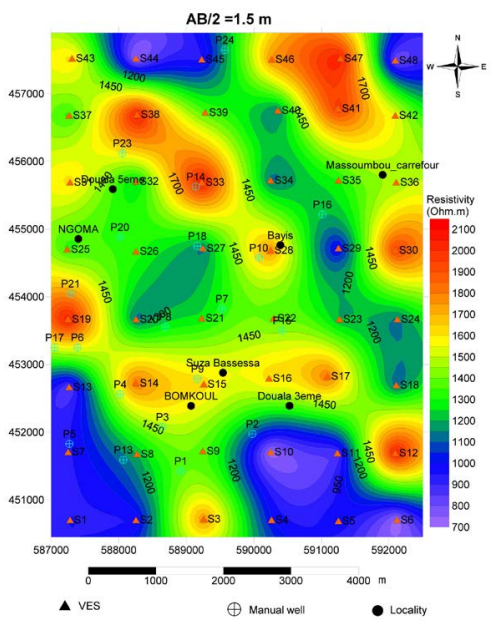

(a)
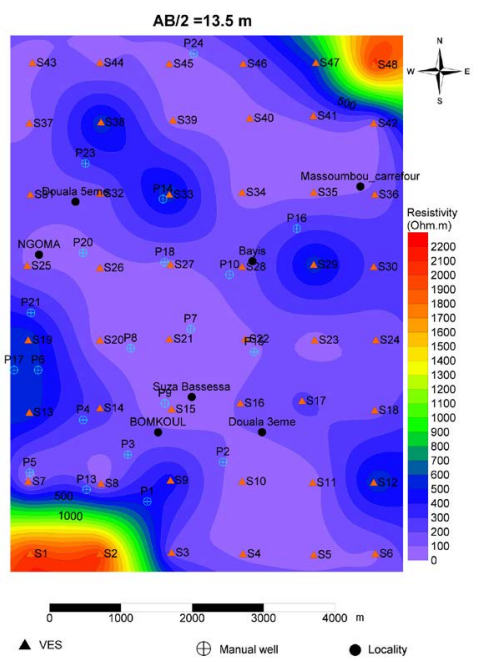

(c)

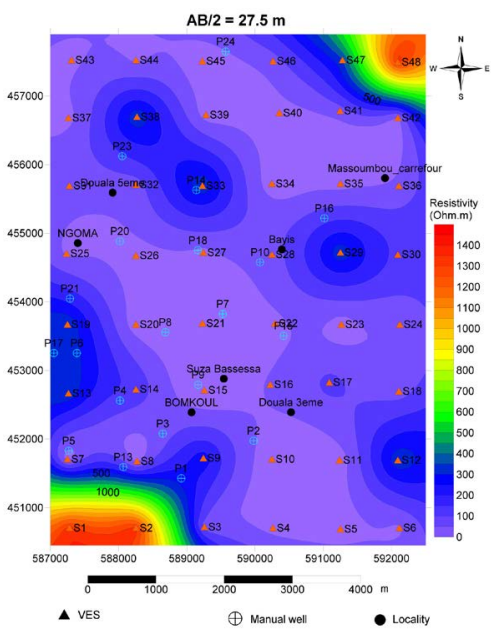

(e)

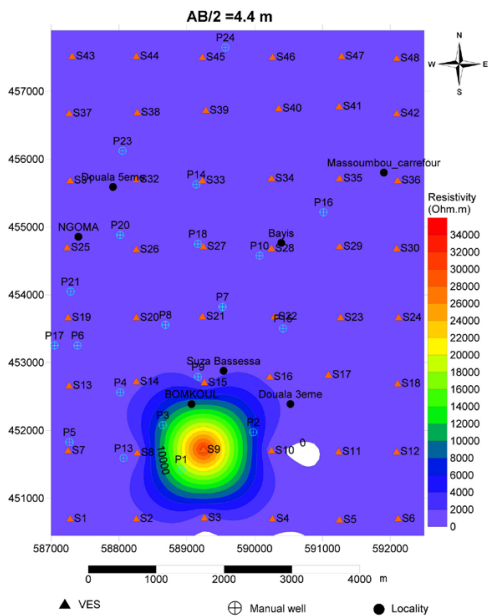

(b)

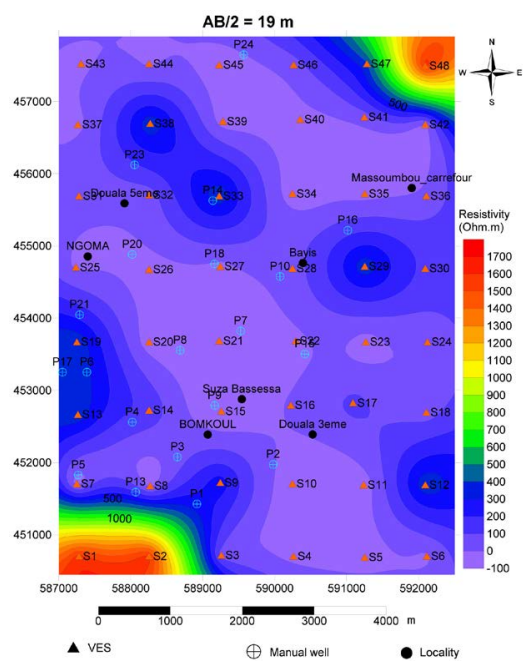

(d)

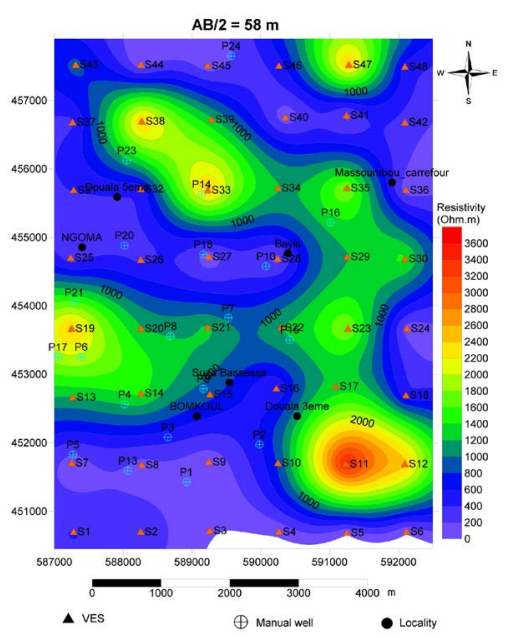

(f)

Figure 3. (a) Isoapparent resistivity map for $A B=3 \mathrm{~m}$; (b) Isoapparent resistivity map for $A B=8.8 \mathrm{~m}$; (c) Isoapparent resistivity map for $A B=27 \mathrm{~m}$; (d) Isoapparent resistivity map for $A B=38 \mathrm{~m}$; (e) Isoapparent resistivity map for $A B=55 \mathrm{~m}$; (f) Isoapparent resistivity map for $A B=116 \mathrm{~m}$. 
It shows a relatively constant resistivity and varying between 0 and $700 \Omega \mathrm{m}$ except stations S1, S2 and S48 where the values of resistivities varies between 700 - $1800 \Omega \mathrm{m}$. This slight variation of the resistivity compared to that obtained with $A B=26.4 \mathrm{~m}$ could reflect the fact that these two resistivity maps are obtained in the same layer. It indicates the presence of aquifer in the area at this depth except the zones of high resistivities.

\section{- Isoapparent electric resistivity map for $A B=55 \mathrm{~m}$}

Figure $3(\mathrm{e})$ represents the lateral variation over a horizontal plane at a depth of about $13.75-18.33 \mathrm{~m}$. The resistivity remains constant $(0-700 \Omega \mathrm{m})$ and points of high resistivity. Remain stations S1, S2 and S48 where the values of resistivities varing from 700 to $1600 \Omega \mathrm{m}$. This slight variation of 2 in the resistivity compared to that obtained with $A B=38 \mathrm{~m}$ could indicate that these two resistivity maps are obtained in the same layer of ground. The aquifer detected within the previous map layers $(A B=26.4 \mathrm{~m}$ and $38 \mathrm{~m})$ is still present.

\section{- Isoapparent electric resistivity map for $A B=116 \mathrm{~m}$}

Figure 3 (f) reflects the lateral variation over a horizontal plane at a depth of about 29 - $38.67 \mathrm{~m}$. Compared to the previous maps, it presents two majors domain: the domain of high resistivity between $1200-3800 \Omega \mathrm{m}$ and that of low resistivity between 0 - $1200 \Omega \mathrm{m}$. Due to lower resistivity of the formations, the second domain could be favorable for groundwater investigation.

The superposition of maps (Figure 4) displays some great variations of resistivity in the first map but whose value is lower compared to that at the next level of $A B / 2=4.4 \mathrm{~m}$. But, from level 1 (for $A B / 2=1.5)$ to level $5(A B / 2=27.5)$ the values of resistivity are decreasing down to $1450 \Omega \mathrm{m}$ at level 5 . Finally from level 5 to level $6(A B / 2=58 \mathrm{~m})$, another increase of resistivity up to $3800 \Omega \mathrm{m}$ is observed. Overall, the values of resistivity vary horizontally and vertically. This may indicate the presence of several structures or valuable material in the study area. The areas of low resistivity could indicate the presence of subsoil aquifers while those of high resistivity could represent the presence of hard intrusive formation.

\subsection{Results from Test Pits}

The description of different layers of clay materials (Table 1) in the study area from 25 traditional test pits make it possible to distinguish five layers of materials with different nature such as sand clay, clay nodular and mottled clay with the thicknesses between 0.2 and $6 \mathrm{~m}$ (Figure 5). The thicknesses of materials change from a layer to another and overall, increase with the depth.

\subsection{Representative Lithologic Section}

In Bomkoul clays, silts, sandstones, nodular clays constitute the major field macroscopic differentiated facies. Several traditional sections located at different topographical levels have revealed thick clay deposits $(19 \mathrm{~m})$ and bottom to top, topped by materials representing almost the entire surface of the area with local 
M. B. Mbog et al.

Table 1. Thickness of layers from test pits.

\begin{tabular}{|c|c|c|c|c|c|c|c|c|c|c|}
\hline \multirow[b]{2}{*}{ Pits } & \multicolumn{2}{|c|}{ Layer 1} & \multicolumn{2}{|c|}{ Layer 2} & \multicolumn{2}{|c|}{ Layer 3} & \multicolumn{2}{|c|}{ Layer 4} & \multicolumn{2}{|c|}{ Layer 5} \\
\hline & $\begin{array}{l}\text { Thickness } \\
\text { (m) }\end{array}$ & Feature & $\begin{array}{l}\text { Thickness } \\
\text { (m) }\end{array}$ & Feature & $\begin{array}{l}\text { Thickness } \\
\text { (m) }\end{array}$ & Feature & $\begin{array}{l}\text { Thickness } \\
\text { (m) }\end{array}$ & Feature & $\begin{array}{l}\text { Thickness } \\
\text { (m) }\end{array}$ & Feature \\
\hline $\mathrm{P} 1$ & $2 \mathrm{~m}$ & Sand clay & $3 \mathrm{~m}$ & Clay nodular & $4 \mathrm{~m}$ & Mottled clay & $6 \mathrm{~m}$ & Sandy clay & $4 \mathrm{~m}$ & $\begin{array}{l}\text { Sandy } \\
\text { clay }\end{array}$ \\
\hline $\mathrm{P} 2$ & $2 \mathrm{~m}$ & Sand clay & $3 \mathrm{~m}$ & Clay nodular & $4 \mathrm{~m}$ & Mottled clay & $6 \mathrm{~m}$ & Sandy clay & $4 \mathrm{~m}$ & $\begin{array}{l}\text { Sandy } \\
\text { clay }\end{array}$ \\
\hline P3 & $2 \mathrm{~m}$ & Sand clay & $3 \mathrm{~m}$ & Clay nodular & $4 \mathrm{~m}$ & Mottled clay & $6 \mathrm{~m}$ & Sandy clay & $4 \mathrm{~m}$ & $\begin{array}{l}\text { Sandy } \\
\text { clay }\end{array}$ \\
\hline $\mathrm{P} 4$ & $2 \mathrm{~m}$ & Sandy clay & $2 \mathrm{~m}$ & Sandstone & $4 \mathrm{~m}$ & Clay & $6 \mathrm{~m}$ & $\begin{array}{l}\text { Compact } \\
\text { clayrich }\end{array}$ & & \\
\hline P5 & $2 \mathrm{~m}$ & Sand clay & $3 \mathrm{~m}$ & Clay nodular & $4 \mathrm{~m}$ & Mottled clay & $6 \mathrm{~m}$ & Sandy clay & $4 \mathrm{~m}$ & $\begin{array}{l}\text { Sandy } \\
\text { clay }\end{array}$ \\
\hline P6 & I & Sand & I & Sand & I & Sand & I & Sand & I & Sand \\
\hline P7 & $2 \mathrm{~m}$ & Sand clay & $3 \mathrm{~m}$ & Clay nodular & $4 \mathrm{~m}$ & Mottled clay & $6 \mathrm{~m}$ & Sandy clay & $4 \mathrm{~m}$ & $\begin{array}{l}\text { Sandy } \\
\text { clay }\end{array}$ \\
\hline P8 & $2 \mathrm{~m}$ & Sand clay & $4 \mathrm{~m}$ & Sandstone & $3 \mathrm{~m}$ & Clay nodular & $4 \mathrm{~m}$ & Mottled clay & $6 \mathrm{~m}$ & Clay \\
\hline P9 & $2 \mathrm{~m}$ & Sand clay & $4 \mathrm{~m}$ & Sandstone & $3 \mathrm{~m}$ & Clay nodular & $4 \mathrm{~m}$ & Mottled clay & $6 \mathrm{~m}$ & Clay \\
\hline $\mathrm{P} 10$ & $2 \mathrm{~m}$ & sandy clay & $2 \mathrm{~m}$ & Sandstone & $4 \mathrm{~m}$ & $\begin{array}{c}\text { Mottled } \\
\text { sandy clay }\end{array}$ & $4 \mathrm{~m}$ & Clay & $6 \mathrm{~m}$ & $\begin{array}{c}\text { Compact } \\
\text { clayrich }\end{array}$ \\
\hline $\mathrm{P} 11$ & $2 \mathrm{~m}$ & Sand clay & $3 \mathrm{~m}$ & Clay nodular & $4 \mathrm{~m}$ & Mottled clay & $6 \mathrm{~m}$ & Sandy clay & $4 \mathrm{~m}$ & $\begin{array}{l}\text { Sandy } \\
\text { clay }\end{array}$ \\
\hline $\mathrm{P} 12$ & $2 \mathrm{~m}$ & Sand clay & $3 \mathrm{~m}$ & Clay nodular & $4 \mathrm{~m}$ & Mottled clay & $6 \mathrm{~m}$ & Sandy clay & $4 \mathrm{~m}$ & $\begin{array}{l}\text { Sandy } \\
\text { clay }\end{array}$ \\
\hline $\mathrm{P} 13$ & $2 \mathrm{~m}$ & Sand clay & $3 \mathrm{~m}$ & Clay nodular & $4 \mathrm{~m}$ & Mottled clay & $6 \mathrm{~m}$ & Sandy clay & $4 \mathrm{~m}$ & $\begin{array}{l}\text { Sandy } \\
\text { clay }\end{array}$ \\
\hline $\mathrm{P} 14$ & $2 \mathrm{~m}$ & Sandy clay & $2 \mathrm{~m}$ & Sandstone & $4 \mathrm{~m}$ & $\begin{array}{c}\text { Mottled } \\
\text { sandy clay }\end{array}$ & $4 \mathrm{~m}$ & Clay & $6 \mathrm{~m}$ & $\begin{array}{l}\text { Compact } \\
\text { clayrich }\end{array}$ \\
\hline $\mathrm{P} 15$ & $2 \mathrm{~m}$ & Sand clay & $3 \mathrm{~m}$ & Clay nodular & $4 \mathrm{~m}$ & Mottled clay & $6 \mathrm{~m}$ & Sandy clay & $4 \mathrm{~m}$ & $\begin{array}{l}\text { Sandy } \\
\text { clay }\end{array}$ \\
\hline $\mathrm{P} 16$ & $20 \mathrm{~cm}$ & $\begin{array}{c}\text { Clay gravel } \\
\text { and sandstone }\end{array}$ & $3 \mathrm{~m}$ & Clay nodular & $4 \mathrm{~m}$ & $\begin{array}{l}\text { Mottled } \\
\text { sandy clay }\end{array}$ & $4 \mathrm{~m}$ & Silts & $4 \mathrm{~m}$ & $\begin{array}{l}\text { Sandy } \\
\text { clay }\end{array}$ \\
\hline $\mathrm{P} 17$ & $2 \mathrm{~m}$ & Sand clay & $3 \mathrm{~m}$ & Clay nodular & $4 \mathrm{~m}$ & Mottled clay & $6 \mathrm{~m}$ & Sandy clay & $4 \mathrm{~m}$ & $\begin{array}{l}\text { Sandy } \\
\text { clay }\end{array}$ \\
\hline $\mathrm{P} 18$ & $20 \mathrm{~cm}$ & $\begin{array}{c}\text { Clay gravel } \\
\text { and sandstone }\end{array}$ & $3 \mathrm{~m}$ & Clay nodular & $4 \mathrm{~m}$ & Silts & $6 \mathrm{~m}$ & Sandy clay & $4 \mathrm{~m}$ & $\begin{array}{l}\text { Sandy } \\
\text { clay }\end{array}$ \\
\hline P19 & $2 \mathrm{~m}$ & Sand clay & $3 \mathrm{~m}$ & Clay nodular & $4 \mathrm{~m}$ & Mottled clay & $6 \mathrm{~m}$ & Sandy clay & $4 \mathrm{~m}$ & $\begin{array}{l}\text { Sandy } \\
\text { clay }\end{array}$ \\
\hline P20 & $2 \mathrm{~m}$ & Sand clay & $3 \mathrm{~m}$ & Clay nodular & $4 \mathrm{~m}$ & Mottled clay & $6 \mathrm{~m}$ & Sandy clay & $4 \mathrm{~m}$ & $\begin{array}{l}\text { Sandy } \\
\text { clay }\end{array}$ \\
\hline $\mathrm{P} 21$ & $2 \mathrm{~m}$ & Sand clay & $3 \mathrm{~m}$ & Clay nodular & $4 \mathrm{~m}$ & Mottled clay & $6 \mathrm{~m}$ & Sandy clay & $4 \mathrm{~m}$ & $\begin{array}{l}\text { Sandy } \\
\text { clay }\end{array}$ \\
\hline P22 & $2 \mathrm{~m}$ & Sandy clay & $2 \mathrm{~m}$ & Sandstone & $4 \mathrm{~m}$ & $\begin{array}{l}\text { Mottled } \\
\text { sandy clay }\end{array}$ & $4 \mathrm{~m}$ & Clay & $6 \mathrm{~m}$ & $\begin{array}{l}\text { Compact } \\
\text { clayrich }\end{array}$ \\
\hline P23 & $2 \mathrm{~m}$ & Sand clay & $3 \mathrm{~m}$ & Clay nodular & $4 \mathrm{~m}$ & Mottled clay & $6 \mathrm{~m}$ & Sandy clay & $4 \mathrm{~m}$ & $\begin{array}{l}\text { Sandy } \\
\text { clay }\end{array}$ \\
\hline $\mathrm{P} 24$ & $2 \mathrm{~m}$ & Nodular clay & $20 \mathrm{~cm}$ & Clay & $2 \mathrm{~m}$ & Nodular clay & $4 \mathrm{~m}$ & Mottled clay & $2 \mathrm{~m}$ & $\begin{array}{l}\text { Sandy } \\
\text { clay }\end{array}$ \\
\hline P25 & $2 \mathrm{~m}$ & Sand clay & $3 \mathrm{~m}$ & Clay nodular & $4 \mathrm{~m}$ & Mottled clay & $6 \mathrm{~m}$ & Sandy clay & $4 \mathrm{~m}$ & $\begin{array}{l}\text { Sandy } \\
\text { clay }\end{array}$ \\
\hline
\end{tabular}




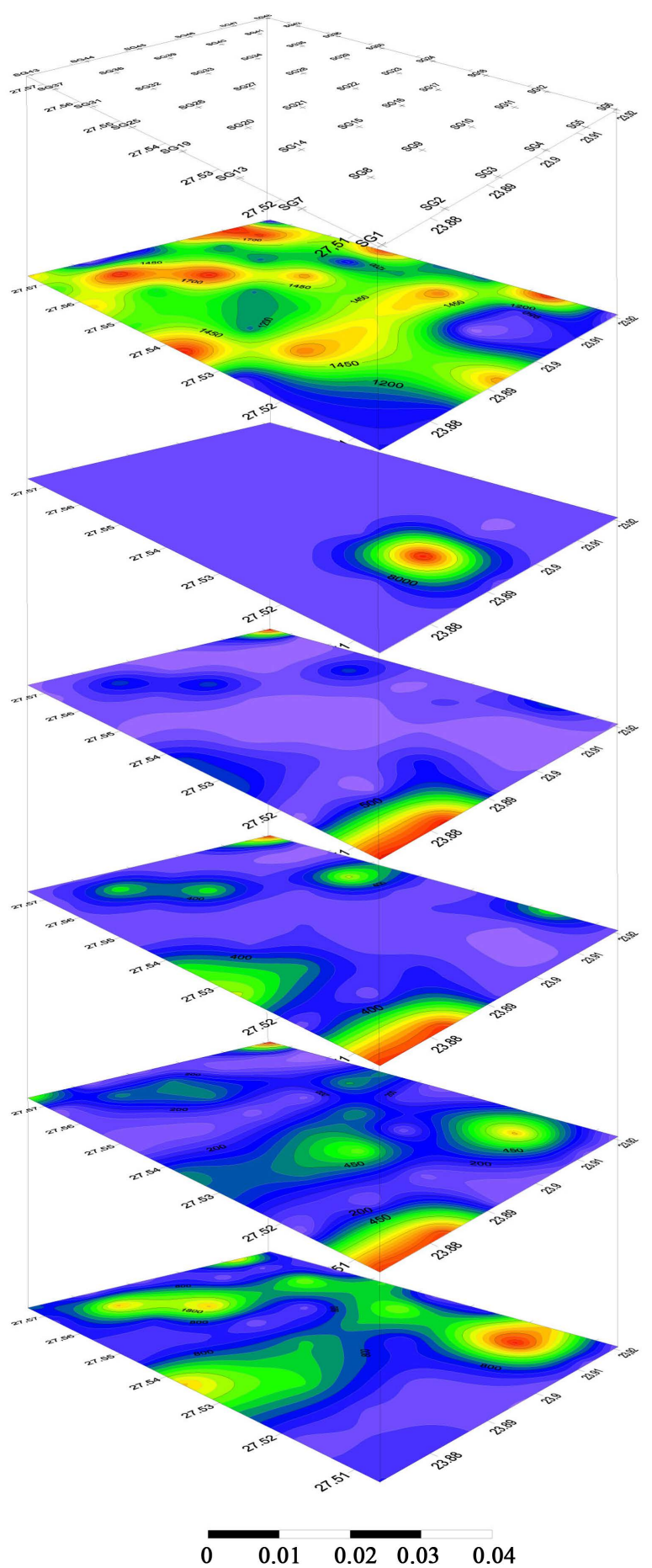

Figure 4. Perspective representation of iso-resistivity maps. It allows analysis on both horizontal and vertical planes.

variations. Fifteen lithofacies were identified and described in Table 1. For the four representative sections of Bomkoul. Their presence in lithologic sections depends on their topographic position: on the upper, medium or lower slopes (Figure 6).

The representative facies are dominated by F1 to F9 and S1 to S3 codes. 


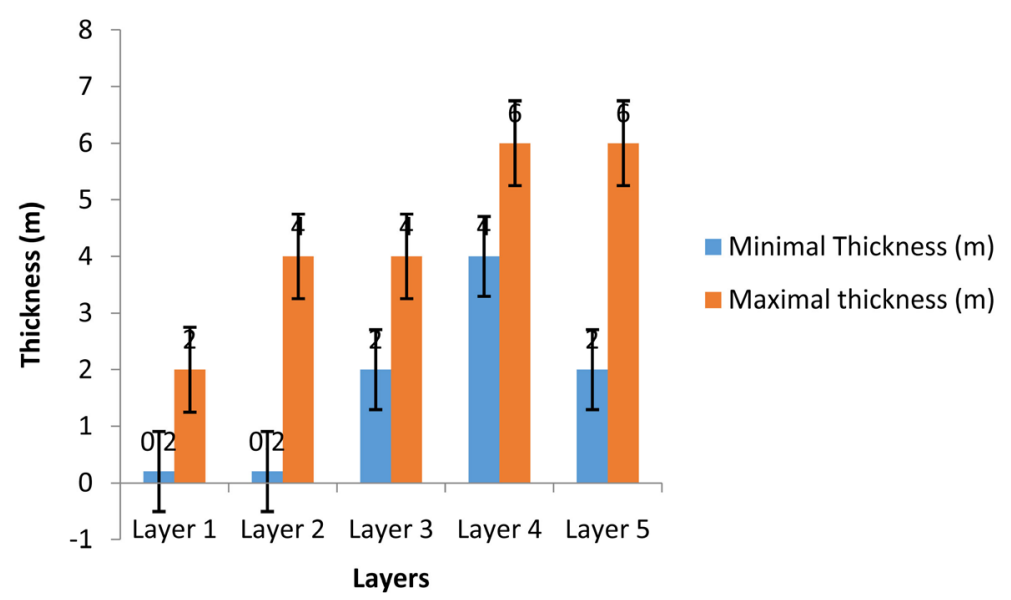

Figure 5. Layers thickness variation.
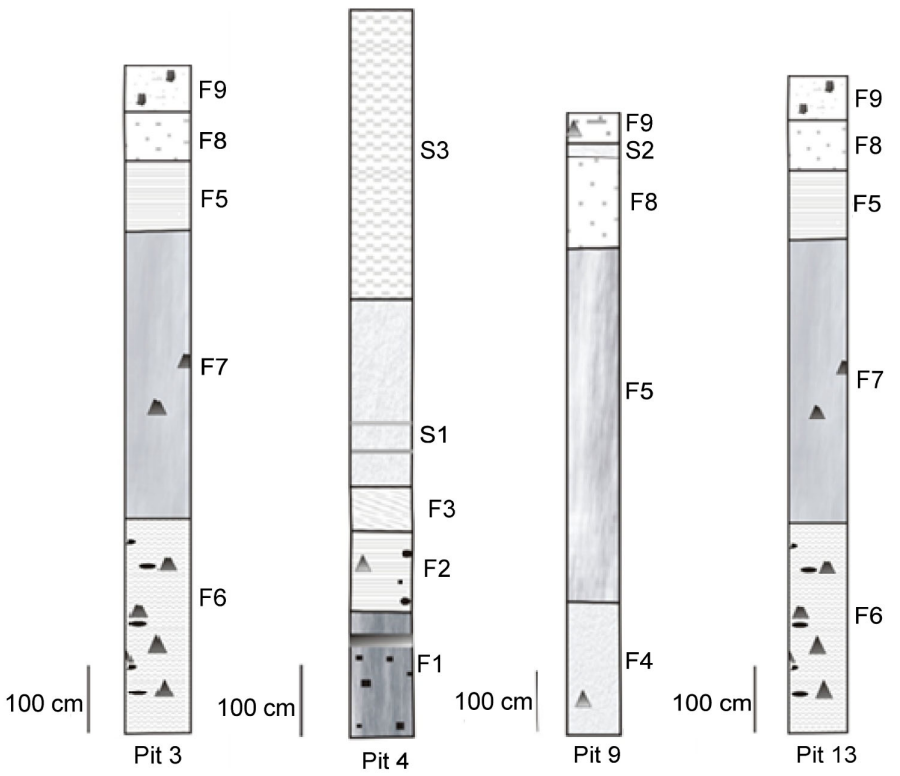

Figure 6. Lithologic section of representative test pit.

\subsection{Facies Code}

A geological survey has permitted the description of the four clayey profiles in terms of texture, structure, distribution and color. The color was obtained using a Munsell soil color chart, and the terminology adopted for the description was that of Miall (1996) and Postma (1990). Fifteen lithofacies were observed in the four profiles and the traditional pits studied (Figure 6, Table 2).

\subsection{Thickness Maps}

Twenty-five pits of 8 to $19 \mathrm{~m}$ were made to study the thickness of the different layers (Figure 7) of land at each station and to deduce their mapping on the horizontal plane. These pits permitted to identify 5 layers of soil with varying thicknesses. Each layer is divided into two domains: a domain of small thicknesses and a domain of large thicknesses. The first layer has a thickness of 0.2 


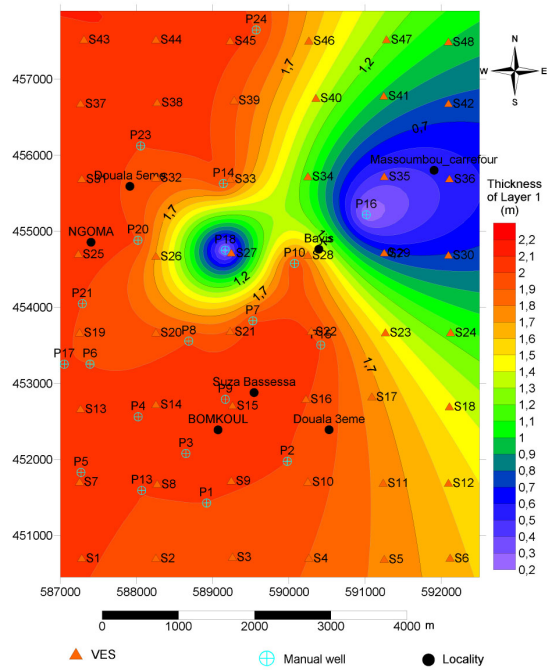

(a)

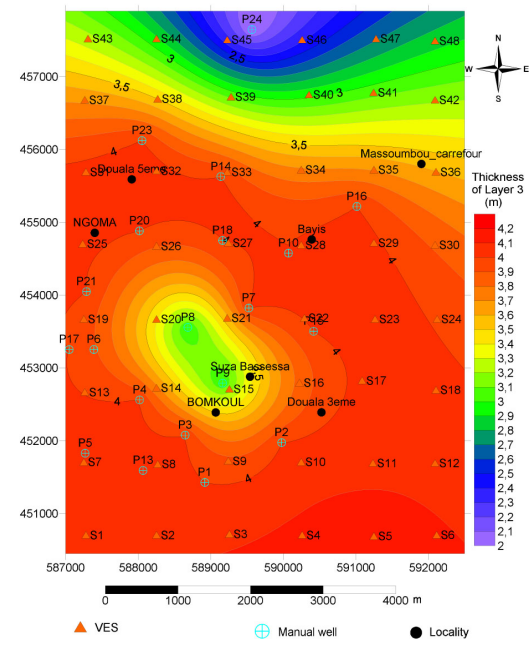

(c)

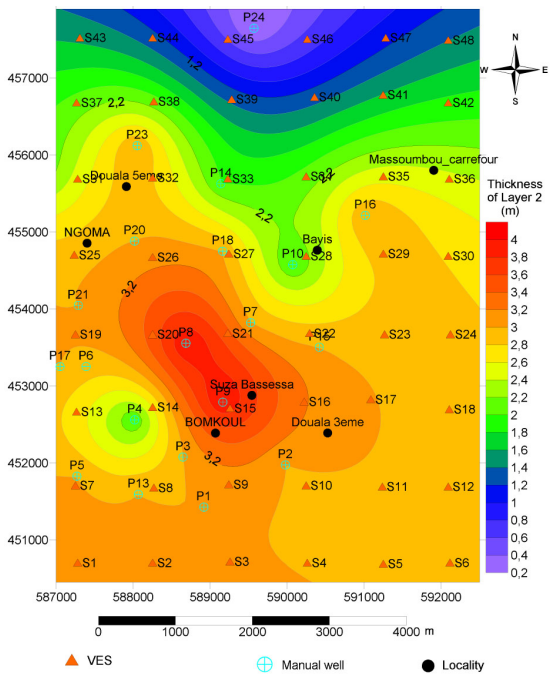

(b)

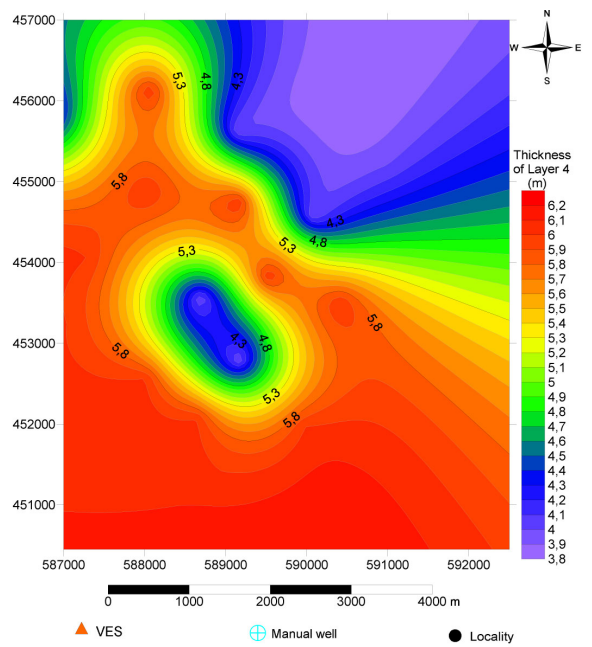

(d)

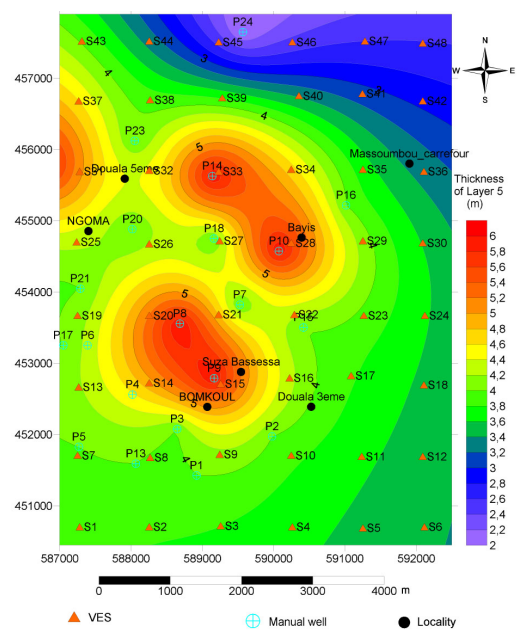

(e)

Figure 7. (a) Thickness variation map of layer 1; (b) Thickness variation map of layer 2; (c) Thickness variation map of layer 3; (d) Thickness variation map of layer 4; (e) Thickness variation map of layer 5 . 
Table 2. Facies codes of the study area and corresponding lithologies according to Miall, 1978 and Postma, 1990.

\begin{tabular}{|c|c|c|c|c|}
\hline $\begin{array}{l}\text { Facies } \\
\text { codes }\end{array}$ & Descriptions & Colour & $\begin{array}{l}\text { Sedimentary } \\
\text { Structures }\end{array}$ & Deposit process \\
\hline S1 & $\begin{array}{l}\text { Sandstone medium to coarse grained } \\
\qquad(30 \mathrm{~cm} \text { to } 2 \mathrm{~m} \text { thickness) }\end{array}$ & $\begin{array}{l}5 \mathrm{Y} 7 / 6 \text { to } \\
5 \mathrm{R} 4 / 6 \text { to } 8 / 1\end{array}$ & $\begin{array}{c}\text { Horizontal laminations, } \\
\text { oblique ferruginous } \\
\text { massive red }\end{array}$ & Cohesive debris flows \\
\hline S2 & $\begin{array}{l}\text { Sandstone horizon end alternating way } \\
\qquad(1-4 \mathrm{~m} \text { thickness })\end{array}$ & $\begin{array}{l}5 \mathrm{R} 4 / 6 \text { to } \\
5 \mathrm{R} 5 / 4\end{array}$ & & \\
\hline S3 & Sandy clay $(2 \mathrm{~m})$ & $5 \mathrm{R} 5 / 4$ & & \\
\hline F12 & Horizon clay gravel and sandstone fragments $(10-20 \mathrm{~cm})$ & $5 \mathrm{R} 4 / 6$ & & \\
\hline F11 & $\begin{array}{l}\text { Horizon nodular clay, } \\
\text { gastropods and bivalves matrix }(1-2 \mathrm{~m})\end{array}$ & $5 \mathrm{R} 4 / 6$ & & \\
\hline F10 & Silts with gastropods and bivalves bioclast $(4 \mathrm{~m})$ & $5 \mathrm{GY} 4 / 1$ & $\begin{array}{l}\text { Subhorizontal } \\
\text { laminations, low } \\
\text { bioturbations, } \\
10 \mathrm{~cm} \text { thickness }\end{array}$ & $\begin{array}{l}\text { Suspension deposit } \\
\text { in a quiet environment }\end{array}$ \\
\hline F9 & Sand micaceous clay, gastropods and bivalves mould $(2 \mathrm{~m})$ & $5 \mathrm{GY} 4 / 1$ & Horizontal laminations & $\begin{array}{l}\text { Planar bed flows with } \\
\text { an average hydrodynamic }\end{array}$ \\
\hline F8 & Horizon clay nodular (2 à $3 \mathrm{~m}$ ) & $\begin{array}{l}5 \mathrm{R} 5 / 4 \text { to } \\
5 \mathrm{Y} 7 / 6\end{array}$ & & \\
\hline F7 & $\begin{array}{l}\text { Micaceous sandy clay, coal, } \\
\text { gastropods and bivalves mould }(6 \mathrm{~m})\end{array}$ & $5 \mathrm{G} 4 / 1$ & $\begin{array}{c}\text { Fine horizontal } \\
\text { laminations, } 60 \mathrm{~cm} \\
\text { thickness }\end{array}$ & $\begin{array}{l}\text { Bed flows (Miall, 1978) } \\
\text { with an average planar } \\
\text { hydrodynamics }\end{array}$ \\
\hline F6 & $\begin{array}{l}\text { Micaceous sandy clay, coal, } \\
\text { gastropods and bivalves mould ( } 4 \mathrm{~m})\end{array}$ & $5 \mathrm{G} 6 / 1$ & Horizontal laminations & \\
\hline F5 & $\begin{array}{c}\text { Mottled clay, plates and } \\
\text { some ferruginous nodules }(2-4 \mathrm{~m})\end{array}$ & $5 \mathrm{R} 4 / 6$ & $\begin{array}{l}\text { Fine horizontal } \\
\text { laminations, } \\
60 \mathrm{~cm} \text { thickness }\end{array}$ & \\
\hline F4 & $\begin{array}{l}\text { Micaceous clay studded with gastropods } \\
\text { moulds and crusts of hardened plates }(6 \mathrm{~m})\end{array}$ & $5 \mathrm{G} 6 / 1$ & Horizontal laminations & $\begin{array}{c}\text { Suspension deposits in a } \\
\text { weak current environment } \\
\text { with low energy (Miall, 1996) }\end{array}$ \\
\hline F3 & $\begin{array}{l}\text { Mottled sandy clay, presence } \\
\text { of some ferruginous nodules }(4 \mathrm{~m})\end{array}$ & $5 \mathrm{Y} 6 / 1$ & Horizontal laminations & $\begin{array}{l}\text { Deposit in the lower part } \\
\text { of a lower flow regime } \\
\text { (Miall, 1978; Postma, 1990) }\end{array}$ \\
\hline F2 & Clay with gastropods moulds and coal $(4 \mathrm{~m})$ & $5 \mathrm{G} 6 / 19+$ & Horizontal laminations & \\
\hline F1 & $\begin{array}{l}\text { Compact clay rich muscovite } \\
\text { and charcoal fragments }(4-6 \mathrm{~m})\end{array}$ & $5 \mathrm{G} 6 / 1$ & Horizontal laminations & \\
\hline
\end{tabular}

and $2.3 \mathrm{~m}$ with small thicknesses (domain 1) observed in the center and east of the study area and varying between 0.2 and $1 \mathrm{~m}$. The second layer presents rather small thicknesses (domain 1) varying between 0.2 and $1.8 \mathrm{~m}$ in the North sector while the large thicknesses (domain 2) varying between 1.8 and $4.2 \mathrm{~m}$ are observed in the rest of the study area with a peak around wells 8 and 9. Layers 3 and 4 have almost the same characteristics: low thickness in the north and center of the map varies between 2 and $3 \mathrm{~m}$ for layer 3 and between 3.8 and $4.8 \mathrm{~m}$ for layer 4 . The fifth layer has small thicknesses (domain 1) varying between 2 and 3.8 
$m$ in the northern sector while the values (domain 2) varying between 3.8 and 6.2 $\mathrm{m}$ are observed in the rest of the study area with peaks around pits 8, 9, 10 and 14 .

Manual pits generally show layer thicknesses ranging from $2 \mathrm{~m}$ to $6 \mathrm{~m}$. The perspective representation (Figure 8) shows the smallest thicknesses less than $3.4 \mathrm{~m}$ in the North sector. The exception is that of the second layer where this zone extends to the center of the map and in the fifth layer where it lies rather in the north-east sector and extends to the center of the study area.

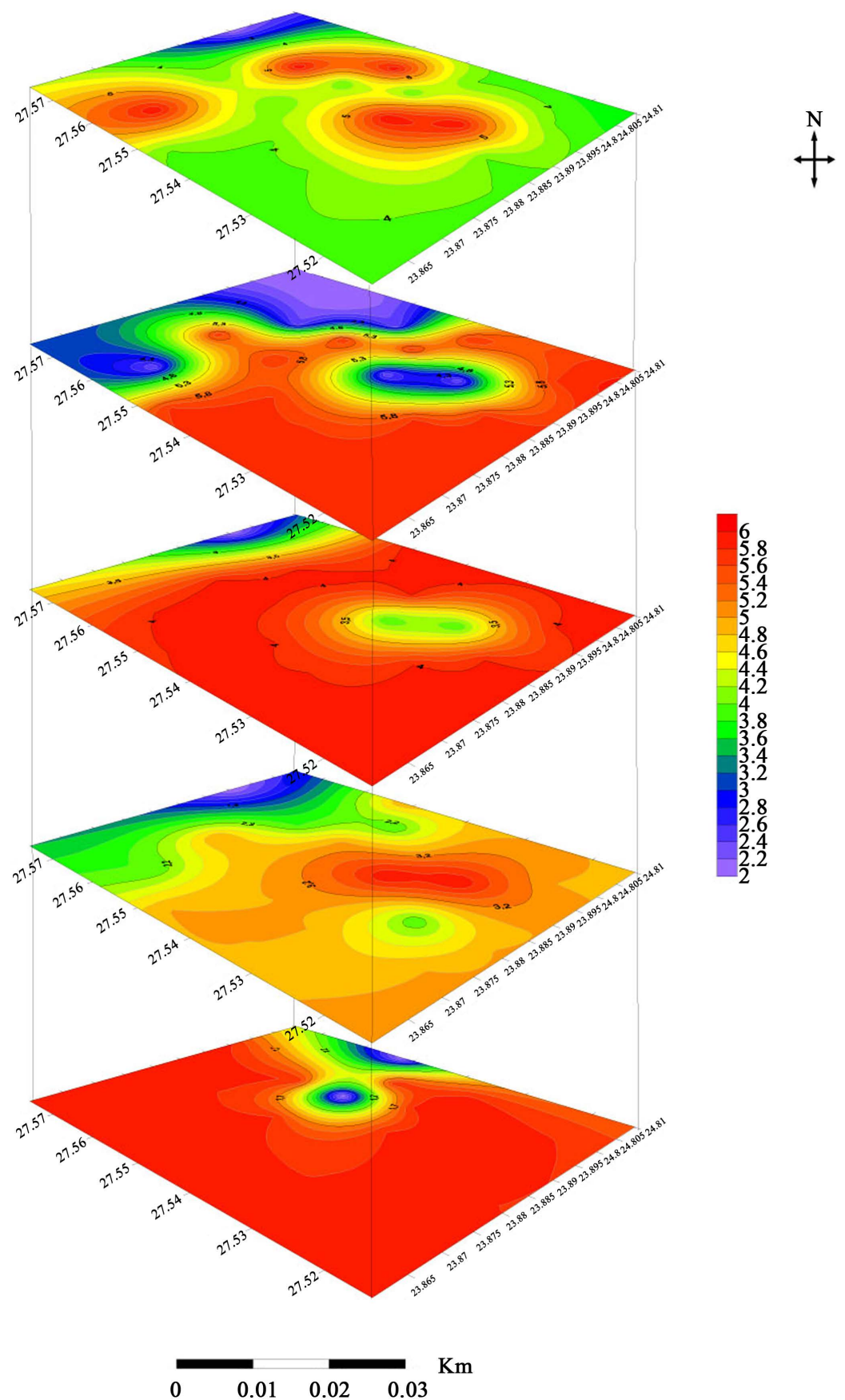

Figure 8. Perspective representation of the thickness of the soil layers obtained from manual pits. 


\section{Discussion and Interpretation}

The analysis of resistivity maps coupled with the maps of the thicknesses of the soil layers obtained from the manual pits reveals information both on the variation of the resistivity of the soil and the geometric characteristics of the different layers of ground situated between the surface and the depth of investigation.

The first layer with an average thickness of $2 \mathrm{~m}$ is located between the surface and approximately $3 \mathrm{~m}$ of depth. The exceptions are P16 and P18 stations where there is a thickness of $20 \mathrm{~cm}$. It has an apparent resistivity varying between 700 and $2000 \Omega \mathrm{m}$ at the first meter, reaching $35,000 \Omega \mathrm{m}$ between 1 to $2 \mathrm{~m}$ deep around the $S 9$ station and a constant value of the resistivity $(2000 \Omega \mathrm{m})$ at this depth for the remaining of stations. The variation of the resistivity at the first layer reflects the distribution of materials of different natures such as sandy clays and lateritic clays while those observed in other zones reflect only the presence of sandy clays.

The high resistivity values $(\geq 2000 \Omega \mathrm{m})$ observed in this layer also reflect the presence of sandy clays, but with a cohesive debris flows like deposit process and a sedimentary structure which are oblique ferruginous massive red and horizontal/subhorizontal laminations. Those of weak resistivities have planar bed flows with an average hydrodynamic deposit process. Planar bed flows with an average hydrodynamic deposit process had been identified by (Mbog et al., 2016). The almost constant resistivity values between 1 and $2 \mathrm{~m}$ depth could indicate homogenization of the soil with an intrusion around the S9 station (Figure 3(b)) which is more extensive between the surface and $1 \mathrm{~m}$ deep (Figure 3(a)).

The thickness of the second layer varies between 2 and $4 \mathrm{~m}$ with the exception of the pit P24 where is $20 \mathrm{~cm}$. It has high resistivity values up to $2300 \Omega \mathrm{m}$ in the northeast and southwest (Figure 3(c) and Figure 3(d)) more precisely around stations S1, S2, S47 and S48. This could reflect the presence of materials of high resistivity. Low values up to $700 \Omega \mathrm{m}$ cover the rest of the study area and reflect the presence of a high-water content material.

The third layer, situated between 5 and $9 \mathrm{~m}$ deep, has an average thickness of $4 \mathrm{~m}$ and the same variation of resistivity as the previous layer, but a slight difference is observed on the nature of the soil which varies between clay, nodular clay, mottled clay and silts.

The fourth layer is located between 9 and $15 \mathrm{~m}$ deep, with a thickness of 4 to 6 $\mathrm{m}$ and the same variation of the resistivity (Figure $3(\mathrm{e})$ ) as the previous layer, but with a variation of the nature of the material which passes from mottled clay to sandy clays.

The fifth studied layer located between 15 and $19 \mathrm{~m}$ depth shows a significant variation of the resistivity (Figure $3(\mathrm{f})$ ) throughout the study area which reflects the presence of clay and sandy clays. Keleko et al.; (2013) reveal in west-cameroon four to five electric layers which corroborate with the present study. The difference between the both results situated on the variation of resistivities values is due to the fact that the present is made in the sedimentary zone which is not the case for their study. 
Odunaike et al. (2013) reveal five to six layers of soil in Ogun State of Nigeria with the topsoil comprising of clay/sand/laterite, sandy clay, clayey sand, coarse sand and hardpan. The information reveals that the subsurface is representing a typical example of a sedimentary environment and the aquifer units.

\section{Conclusion}

According to the results of the resistivity survey carried out in the Douala sub-basin, it is now possible to reach the following conditions: the study of isoapparent resistivity maps showed that, generally the direction of resistivity contours is NW-SE approximately. This direction corresponds to the direction of a temporary river that drains the area. The distribution of apparent resistivity values in all maps showed that high values are due to coarse grain talus. Also, in other parts of the study area, the apparent resistivity values are the lowest due to fine grain alluvium. Five major layers were identified from the results of qualitative and quantitative interpretation of test pits in the sub basin. The first layer is interpreted as near-surface layer and has highly variable resistivity ranging from about 700 to $35,000 \Omega \mathrm{m}$ and a thickness of less than $1.9 \mathrm{~m}$. The second one is dry alluvium layer with a resistivity of less than $2300 \Omega \mathrm{m}$ and a thickness of more than $4 \mathrm{~m}$. The third layer that corresponds to the saturated layer has a resistivity and thickness of less than $2300 \Omega \mathrm{m}$ and $4 \mathrm{~m}$ respectively. The fourth layer is interpreted as a coarse-grained sand. This layer in most parts of the area is probably slate with a resistivity varying from $700 \Omega \mathrm{m}$ to $1600 \Omega \mathrm{m}$ and the thickness of $2 \mathrm{~m}$.

\section{Acknowledgements}

The authors are grateful to all participants of the field works specially Pr Jacques ETAME.

\section{Conflicts of Interest}

The authors declare no conflicts of interest regarding the publication of this paper.

\section{References}

Banton, O., \& Bangoy, L. M. (1997). Hydrogéologie multiscience environnementale des eau souterraines (p. 460).

Brownfield, M. E., \& Charpentier, R. R. (2006). Geology and Total Petroleum Systems of the West-Central Coastal Province (7203), West Africa. US Geological Survey Bulletin, 2207-B, $52 \mathrm{p}$.

Danielsen, F., Mendoza, M. M., Tagtag, A., Alviola, P. A., Balete, D. S., Jensen, A. E., Enghoff, M., \& Poulsen, M. K. (2017). Increasing Conservation Management Action by Involving Local People in Natural Resource Monitoring. Ambio, 36, 566-570.

https://doi.org/10.1579/0044-7447(2007)36[566:ICMABI]2.0.CO;2

Dartevelle, E., \& Brebion, P. (1956). Mollusques fossiles du Crétacé de la Côte occidentale d'Afrique du Cameroun a l'Angola. Ann. Musée Royal Congo Belge, Science Geologiques. 
Tervuren I-Gastéropodes, 8, 1-128.

Dartevelle, E., Freinex, S., \& Sornay, J. (1957). Mollusques fossiles du Crétacé de la Côte occidentale d'Afrique du Cameroun a l'Angola. Ann. Musée Royal Congo Belge, Science Geologiques. Tervuren II-Lamellibranches, 8, 1-271.

Dumort, J. F. (1968). Identification par la télédétection de la Sanaga (Cameroun). Géodynamique, 1, 13-19.

Elimbi, A., \& Njopwouo, D. (2002). Propriétés des produits de cuisson de deux argiles kaolinitiques de l'Ouest du Cameroun. Silicates Industriels, 66, 121-125.

Frohlich, R. K., Fisher, J. J., \& Summerly, E. (1996). Electric Hydraulic Conductivity Correlation in Fractured Crystalline Bedrock: Central Land-Fill, Rhode Island, USA. Journal of Applied Geophysics, 35, 249-259. https://doi.org/10.1016/0926-9851(96)00028-6

Keleko, A. T. D., Tadjou, J. M., Kamguia, J., Tabod, C. T., Feumoe, S. A. N., \& Kenfack, J. V. (2013). Groundwater Investigation Using Geoelectrical Method: A Case Study of the Western Region of Cameroon. Journal of Water Resource and Protection, 5, 633-641. https://doi.org/10.4236/jwarp.2013.56064

Maliengoue, M. A. M. (2010). Cartographie des affleurements de la localite de Bomkoul (sous-bassin de Douala) (24 p.). Douala: Memoire, DEA, Facultedes Sciences, Universite de Doula.

Mbog, M. B. (2010). Etude morphologique, physico-chimique et minéralogique des argiles de Bomkoul dans le sous bassin sédimentaire de Douala-Cameroun (60p.). Douala: Faculté des Sciences, Université de Douala, Mémoire. D.E.A.

Mbog, M. B. (2016). Caractérisations Géophysique, Physico-chimique, Minéralogiqueet Géochimique des argiles de Bomkoul et de Ngoma dans le sous bassin de douala (171 p.). Douala: Cameroun Thèse, Faculté des Sciences, Université de Douala.

Mbog, M. B., Ngon Ngon, G. F., Etame, J., Djieto, L. A., Tassongwa, B., \& Bilong, P. (2016). Vertical Electrical Sounding VES. Investigation of Aquifer and Potential Clay Materials in Douala Subbasin (Cameroon, Central Africa). Earth Science Research, 5, 1-14. https://doi.org/10.5539/esr.v5n1p94

Miall, A. D. (1996). The Geology of Fluvial Deposits: Sedimentary Faciès, Basin Analysis, and Petroleum Geology (582 p.). Berlin: Springer-Verlag.

Ngon Ngon, G. F., Etame, J., Ntamak, M. J., Mbog, M. B., \& Maliengoue, A. M. (2012). Geological Study of Sedimentary Clayey Materials of the Bomkoul Area in the Douala Region (Douala Sub-Basin, Cameroon) for the Ceramic Industry. Comptes Rendus Geoscience, 344, 366-376. https://doi.org/10.1016/j.crte.2012.05.004

Nguene, F. R., Tamfu, S., Loule, J. P., \& Ngassa, C. (1992). Paleoenvironment of the Douala and Kribi/Campo Subasins in Cameroon, West Africa. Géologie Africain; Coll Géol. Libreville, recueil des communic 6-8 May 1991.

Njike Ngaha, P. R. (1984). Contribution à étude géologique, stratigraphie et structurale de la bordure $d u$ bassin atlantique $d u$ Cameroun (131 p.). Thèse $3^{\mathrm{e}}$ cycle, Yaoundé: Université de Yaoundé.

Njopwouo, D. (1984). Minéralogie et physico-chimie des argiles de Bomkoul et Balengou (Cameroun). Utilisation dans la polymérisation du styrène et dans le renforcement du caouthouc naturel (300 p.). Thèse. Doct. d'Etat, Yaoundé: Univ. Yaoundé.

Njopwouo, D., \& Kong, S. (1986). Minéralogie de la fraction fine des matériaux argileux de Bomkoul et de Balengou (Cameroun). Annales Faculté des Sciences, Série Science-Chimie I, 1-2, 17-31.

Njopwouo, D., \& Wandji, R. (1985). Minéralogie de l'argile kaolinique de Bomkoul 
(Cameroun). Revue Science Technologie, Série Science I, 3-4, 71-81.

Odunaike, R. K., Fasunwon, O. O., Akinyemi, L. P., \& Odusote, O. O. (2013). Physico-Chemical Characterization of Oil Sands at Imeri in Ogun State of South West, Nigeria.

Postma, G. (1990). Depositional Architecture and Facies of River and Fan Deltas: A Synthesis. In A. Colella, \& D. B. Prior (Eds.), Coarse-Grained Deltas 10 (pp. 13-28). Hoboken, NJ: Wiley. https://doi.org/10.1002/9781444303858.ch2

Regnoult, J. M. (1986). Synthèse géologique du Cameroun D.M.G. Yaoundé, Cameroun (118 p.).

Reyre, D. (1966). Histoire géologique du bassin de Douala. In D. Reyre (Ed.), Symposium sur les bassins sédimentaires du littoral africain (pp. 143-161). Association du Service Géologique d'Afrique, IUGS.

Riedel, L. (1932). Die Oberkreide von Mungofluss in Kamerun und ihre Fauna (pp. 1-154). Beitrage zur Geologie Erforsch. dt. Schutzeb. Berlin 16.

SNH/UD (2005). Stratigraphie séquentielle et tectonique des dépôts mésozoïques syn-rifts du bassin de Kribi/Campo (134 p.). Rapport non publié.

Solger, F. (1904). Die Fossilien der Mungokreide im Kamerun und ihre geologische Bedentung, mit besonderer Berûcksichtingung der Ammonitiden. In E. Esch, F. Solger, M. Oppenheim, \& O. Jakel (Eds.), Beitrage zur Geologie Von Kamerun (Vol. 1, pp. 83-242).

Von Koenen, A. (1896). Ueber Fossilien der unteren Kreide am Ufer des Mungo im Kamerun (pp. 1-48). Abhandlungen der kôniglichen Gesellschaft der Wissenschaften zu Gottingen, Neue Folge Band 1 Nr 1.

Zohdy, A. A., Eaton, C. P., \& Mabey, D. R. (1974). Application of Surface Geophysics to Groundwater Investigation. Washington DC: Tech. Water Resources Investigation, U.S. Geological Survey No. 2401. 